Note

\section{Thermal Stability of Free and Immobilized Glucose Oxidase Studied by Activity Assay and Calorimetry}

\author{
Hisao Ichijo, Hatsuho UedaIRA, \\ Tetsuro Suehiro, Jun'ichi Nagasawa, \\ Aizo Yamauchi and Noboru AISAKa \\ Research Institute for Polymers and Textiles, 1-1-4, \\ Higashi, Tsukuba, Iharaki 305, Japan
}

Received August 9, 1988

In our previous paper, we reported that the thermal stability of invertase measured by calorimetry agreed well with that which was measured by an activity assay ${ }^{1)}$ and we described the effects of $\mathrm{pH}$ and enzyme loading on the thermal stability of invertase on poly(vinyl alcohol) super fine fibers (SFF). ${ }^{2}$ More research should be done to confirm that the calorimetric method for evaluating thermal stability can be generally applied to other enzymes containing different amount of carbohydrates.

In this work, the thermal stability of glucose oxidase in solution and immobilized on SFF was measured by an activity assay and calorimetry.

Glucose oxidase (EC 1.1.3.4) from Aspergillus niger was purchased from the Sigma Chemical Co. The glucose oxidase gave a single band by isoelectric forcusing and SDS poly(acrylamide) gel electrophoresis. For activity assay, the decrease in dissolved oxygen (DO) was continuously measured by a DO meter (Central Kagaku Co., Ltd.) at $20^{\circ} \mathrm{C}$. An SSC/560U (Seiko Instruments \& Electronics Ltd.) calorimeter was used to study free and immobilized samples.

The denaturation temperature $\left(T_{\mathrm{d}}\right)$ of free and immobilized glucose oxidase increases with the decrease in $\mathrm{pH}$ and reaches the highest value at pH 5.4 (see Table I), which agrees with the results of the denaturation rate studies for free glucose oxidase by Bouin et al ${ }^{3)}$ The isoelectric point of glucose oxidase from $A$. niger was reported to be $\mathrm{pH}$ $4.3 .^{4)}$ As shown in Table $I$, the enzyme is stabilized at the $\mathrm{pH}$ close to its isoelectric point. $T_{\mathrm{d}}$ for the glucose oxidase bound on SFF is higher than that for free enzyme. The data mean that the immobilization by SFF increases the thermal stability of the enzyme. The results from the glucose oxidase on SFF are similar to those of the invertase on SFF, but the $T_{\mathrm{d}}$ difference between free and immobilized enzyme is less for glucose oxidase than for invertase.

The calorimetric enthalpy change, $\Delta H_{\mathrm{d}}$, of free and immobilized glucose oxidase also increases with the decrease in $\mathrm{pH}$ as shown in the table. $\Delta H_{\mathrm{d}}$ for the immobilized enzyme is larger than that for the free one, which confirms the stabilizing effect by the immobilization on SFF.

Figure 1 shows the effects of $\mathrm{pH}$ and enzyme loading on the thermal stability of the glucose oxidase immobilized on SFF. The figure shows that $T_{\mathrm{d}}$ increases with increasing enzyme loading. The thermal stability of the glucose oxidase on SFF is more dependent on $\mathrm{pH}$ than on enzyme loading. On the other hand, the thermostability of the invertase immobilized on SFF was influenced by enzyme loading much more than by $\mathrm{pH} .{ }^{2}{ }^{2}$ Komori et al. reported a similar concentration effect on thermal stability, that is, the enhancement of the thermodurability of glucose oxidase

Table I. Dependence of Denaturation TEMPERATURE AND DENATURATION ENTHALPY ON $\mathrm{pH}$

\begin{tabular}{lccc}
\hline & $\mathrm{pH}$ & $\begin{array}{c}\text { Denaturation } \\
\text { temperature } \\
T_{\mathrm{d}}\left({ }^{\circ} \mathrm{C}\right)\end{array}$ & $\begin{array}{c}\text { Denaturation } \\
\text { enthalpy } \\
\Delta H_{\mathrm{d}}(\mathrm{J} / \mathrm{g})\end{array}$ \\
\hline Free & 5.4 & 66.7 & 11.45 \\
& 6.7 & 63.8 & 9.70 \\
& 7.9 & 57.9 & 9.24 \\
\hline Immobilized & 5.4 & 70.0 & 18.48 \\
& 6.7 & 64.7 & 14.50 \\
& 7.9 & 60.5 & 12.37 \\
\hline
\end{tabular}

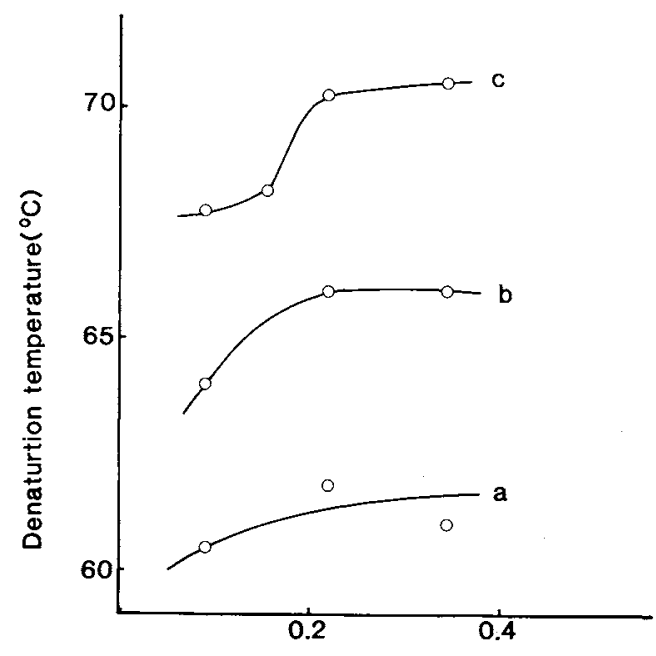

Enzyme loading(g-Enz./g-dry SFF)

Fig. 1. Effects of $\mathrm{pH}$ and Enzyme Loading on Denaturation Temperature.

a, pH 7.9; b, pH 6.7; c, pH 5.4 . 


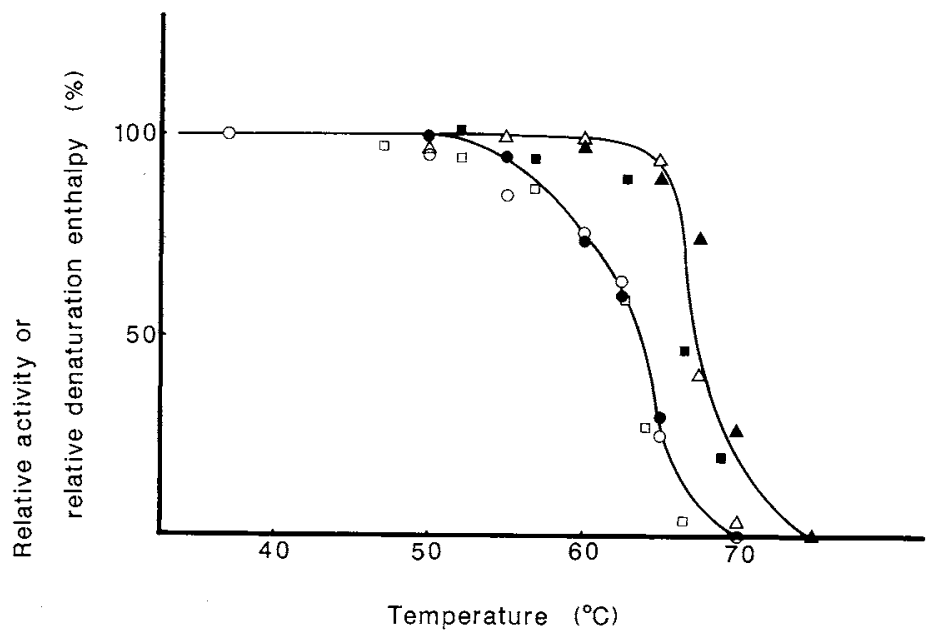

Fig. 2. Thermal Stability of Free and Immobilized Glucose Oxidase.

$O$, free; $\triangle$, immobilized, Open symbols are results from activity assay and closed symbols from thermal analysis.

$\square$, free ${ }^{5)} \mathbf{\square}$, microcapsulated. ${ }^{5 \text { ) }}$

by an increase in the amount of the enzyme entrapped in polyurea microcapsules. ${ }^{5}$ )

The relative activity and relative denaturation enthalpy for heat-treated samples are plotted against the temperature of the heat treatment ${ }^{1)}$ (see Fig. 2). The results from thermal analysis agree with those from the activity assay, especially for the free enzyme. Free glucose oxidase starts denaturing at around $50^{\circ} \mathrm{C}$, while the immobilized enzyme keeps its original activity and its original conformation up to $60^{\circ} \mathrm{C}$. The bound glucose oxidase heated to $65^{\circ} \mathrm{C}$ keeps $94 \%$ of its original activity, while the free one heated to $65^{\circ} \mathrm{C}$ keeps only $25 \%$. The glucose oxidase immobilized on $\mathrm{SFF}$ is more thermostable than that in solution. The data by Komori et al. are also plotted in Fig. 2. Although the way of heating the enzyme is different, the stability of free glucose oxidase obtained from our experiments is almost the same as that measured by them. The figure shows that the microcapsulated enzyme starts denaturing at a slightly lower temperature than the enzyme on SFF, which would support that SFF is an excellent material for immobilization. ${ }^{6,7)}$ The immobilization on SFF may lead to prevention of the conformational change of enzymes. It was reported that carbohydrates and polyhydric alcohols had a stabilizing effect on enzymes. ${ }^{8,9)}$ Swoboda et al. reported that glucose oxidase from $A$. niger contained about $16 \%$ carbohydrate. ${ }^{10)}$ Invertase containing $50 \%$ carbohydrate was more stabilized by the immobilization than glucose oxidase. On the other hand, the thermal stability of $\beta$-galactosidase from $E$. coli, which has no carbohydrate, ${ }^{11}$ was not improved by immobilization on
SFF. ${ }^{6)}$ Therefore, the thermostability of enzyme seems to have a close relationship with the cabohydrate content of the enzyme.

Acknowledgment. The authors wish to thank Dr. T. Kokubu of the Research Institute for Polymers and Textiles for his discussion and help in electrophoresis.

\section{References}

1) H. Ichijo, H. Uedaira, T. Suehiro, J. Nagasawa and A. Yamauchi, Agric. Biol. Chem., 49, 3591 (1985).

2) H. Uedaira, H. Ichijo, J. Nagasawa, T. Suehiro and A. Yamauchi, Thermochim. Acta, 123, 183 (1988).

3) J. C. Bouin and H. O. Hultin, Biotechnol. Bioeng., 24, 1225 (1982).

4) Seikagaku-Kogyo, Personal communication.

5) T. Komori, N. Muramatsu and T. Kondo, $J$. Microencapsulation, 3, 219 (1986).

6) H. Ichijo, Ph. D. Thesis (1987).

7) H. Ichijo, T. Suehiro, A. Yamauchi, S. Ogawa, M. Sakurai and N. Fujii, J. Appl. Polym. Sci., 27, 1665 (1982).

8) H. Uedaira, Sen-i Gakkaishi, 37, P-436 (1981).

9) K. Gekko, J. Biochem., 91, 1197 (1982).

10) B. E. P. Swoboda and V. Massey, J. Biol. Chem., 240 , 2209 (1965).

11) A. V. Fowler and I. Zabin, Proc. Natl. Acad. Sci. U.S.A., 74, 1507 (1977). 